\title{
Clinical features and treatment outcomes in children with idiopathic thrombocytopenic purpura: a single center's experience
}

\section{Çocukluk çağında idyopatik trombositopeník purpuralı hastaların klinik özellikleri ve tedavi sonuçları: tek merkez deneyimi}

\author{
Utku Aygüneş
}

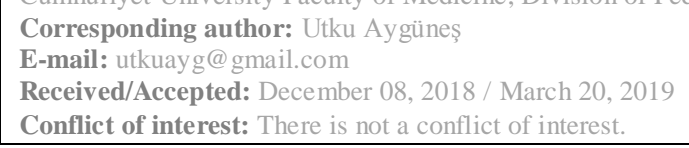

\section{SUMMARY}

Objective: Childhood idiopathic thrombocytopenic purpura (ITP) is a common disorder. The objective of this study is to review presenting features and response to therapy of ITP treated at a single pediatric medical center.

Method: A retrospective chart review was made for all children (ages birth-18 years) diagnosed with ITP and treated at the Sivas Cumhuriyet University Hospital. Files of children with ITP were retrospectively reviewed. There were 156 children with newly diagnosed ITP and 36 children with chronic ITP. The diagnosis of ITP was based on the exclusion of other causes of thrombocytopenia by detailed history, physical examination, complete blood count with blood smear and bone marrow examination.

Results: There was no significant difference in median charges for the intravenous immunoglobulin (IVIG), prednisolone (IV) and mega-dose methylprednisolone (MDMP) groups for the initial treatment of ITP. History of antecedent infection and vaccination were present in $44.2 \%$ and $8.3 \%$ of the patients, respectively. At diagnosis, $76.4 \%$ of the patients had a platelet count of $<10,000 / \mu 1$ but only $11.1 \%$ had major bleedings. Intracranial hemorrhage was seen in two patients $(1 \%)$ with a mortality rate of $0.05 \% .5 .1 \%$ developed chronic ITP.

Conclusions: These data show that mode of treatment has no effect on the clinical course and prognosis of childhood ITP. However, the IVIG was significantly more expensive than steroids.

Keywords: Child, immune thrombocytopenic purpura, immunoglobulin, steroid

\section{ÖZET}

Amaç: İmmün trombositopenik purpura çocukluk çağında sık görülen, trombositopeni ile seyreden bir hastalıktır. Tek merkezde yapılan bu çalışmanın amacı çocukluk çağında ITP hastalarında başlangıç klinik bulguları ve tedaviye yanıtın değerlendirilmesidir.

Yöntem: Sivas Cumhuriyet Üniversitesi Hastanesi Çocuk hematoloji-onkoloji polikliniğinde 0-18 yaș grubunda ITP tanısı almış hastaların dosyaları geriye doğru tarandı. 156 akut, 36 kronik ITP'li hastanın detaylı anamnez özellikleri, fizik muayene bulguları, tam kan sayımı ve yapılmış ise kemik iliği aspirasyon sonuçları kaydedildi.

Bulgular: Intravenöz immunoglobulin, intravenöz prednisolon ve yüksek doz prednisolon ile tedavi edilen hastaların tedavi sonuçları arasında anlamlı fark görülemedi. Hastaların yakın zamanda geçirilmiş enfeksiyon öyküsü ve aşılama

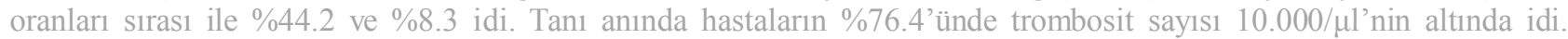
Ancak sadece \%11.1 kadarında majör kanama görüldü. İntrakranyal kanama yanlızca 2 hastada (\%1) görüldü. Mortalitesi \% 0.05 idi. Akut ITP hastalarının \% 5.1'inde kronikleşme görüldü.

Sonuç: Çalışmamızda ITP hastalarında prognozun tedavi ile ilişkili olmadığı görüldü. IVIG için dışa bağımlı ülkeler için ITP tedavisinde daha ucuza temin edilebilen prednisolon tercih etmek tedavi maliyetini düşürecektir.

Anahtar sözcükler: Çocuk, immün trombositopenik purpura, immunoglobulin, steroid 


\section{INTRODUCTION}

Immune thrombocytopenic purpura is an acquired autoimmune hematologic condition characterized by destruction of platelets leading to isolated thrombocytopenia and and mucocutaneous bleeding $^{1,2}$. It is mostly a self-limiting ailment in otherwise healthy children presenting with bruising, purpura, petechiae, mucosal bleeding, and thrombocytopenia, plasma anti-platelet antibodies, and rise in megakaryocytes ${ }^{3}$. Serious bleedings generally occur when platelet count (PC) falls below 20,000/ $\mu$ l. In the majority of the children, it is benign disease with complete recovery of the platelets. However, $20 \%$ to $30 \%$ of children develop the chronic form of the disease ${ }^{4}$.

\section{MATERIAL AND METHODS}

Cases were identified by reviewing hospital records for all patients with the discharge diagnosis of idiopathic thrombocytopenic purpura treated in division of Pediatric HematologyOncology at the Sivas Cumhuriyet University Hospital. A total of 192 patients (156 newly diagnosed ITP and 36 children with chronic ITP) with the diagnosis of ITP were identified. The diagnosis was based on clinical history as well as physical examination along with tests revealing isolated thrombocytopenia (platelet count $<100 \times 10^{9} / \mathrm{L}$ ), normal peripheral blood smear, white blood cells, and no underlying malignancies and other causes of thrombocytopenia. Blood counts were done by a Coulter Hematology Analyzer. Details on bone marrow examination if carried out were also collected. Chronic ITP was defined as persistent thrombocytopenia, lasting greater than six months after the initial diagnosis. The study got the approval from the institutional Ethics Committee. Direct antiglobulin test, antinuclear antibodies, serum immune globulin levels, antibodies to cytomegalovirus (CMV), Epstein-Barr virus (EBV), herpes simplex virus, rubella, Parvovirus B19, human immunodeficiency virus, and hepatitis $\mathrm{A}, \mathrm{B}$ and $\mathrm{C}$ viruses were performed in all children at initial pesentation. Bleeding was classified as serious if there was gastrointestinal (GI), genitourinary (GU), central nervous system (CNS), joint, or nasal or oral bleeding requiring packing, menorrhagia, widespread mucosal bleedings at more than one site or the need for transfusions, antifibrinolytic therapy, endoscopy, or hospitalization for the management of bleeding ${ }^{5}$. Patients with normalization of their platelet count, even if due only to therapy, were classified as acute ITP if they did not have a documented platelet count follow up at 6 months. Persistence of thrombocytopenia more than six months after diagnosis was defined as chronic ITP. Patients were classified as chronic ITP if the platelet count at 12 months was $<150,000 / \mathrm{mL}$. Treatment was given to children with either platelet count of less than 10x109/L and/or severe bleeding symptoms. Children with minor and/or mucous bleeding symptoms with platelet count of less than $20 \times 10^{9} / \mathrm{L}$ to $30 \times 10^{9} / \mathrm{L}$ were closely observed and received treatment on demand ${ }^{6}$. Prednisolone at 3$5 \mathrm{mg} / \mathrm{kg} /$ day for 3-7 days IV, MDMP $30 \mathrm{mg} / \mathrm{kg}$ for 3 days and IVIG at $1 \mathrm{~g} / \mathrm{kg} /$ day for 2 days were the initial therapeutic options. Response to treatment was defined as partial response (PR)

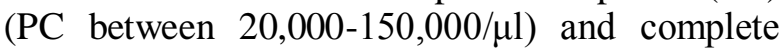
response $(\mathrm{CR})(\mathrm{PC}>150,000 / \mu \mathrm{l})$. Any platelet count lower than $20 \times 10^{9} / \mathrm{L}$ was described as "no response" ${ }^{7}$. PC $\left.<20,000 / \mu l\right)$ time after complete or partial responseData were analyzed using an SPSS program, and the results were shown as mean and standard deviation (mean \pm SD). Mann-Whitney $\mathrm{U}$ and Kruskal-Wallis tests were used for statistical analysis, and $\mathrm{p}<0.05$ was accepted as the significance level.

\section{RESULTS}

The records of 99 males and 93 females with ITP between ages 0 and 18 years were evaluated. In 156 children with newly diagnosed ITP, the presenting symptoms were simple skin petechiae $(13 \%)$, ecchymoses $(14 \%)$, petechiae and ecchymoses (38\%), gingival bleeding $(6 \%)$ and epistaxis (29\%). 16 (10.2\%) of 156 children presented with major bleedings as epistaxis requiring nasal package (n: 7), intracranial hemorrhage with acute ITP (n: 1) and chronic ITP (n: 1), macroscopic hematuria (n: 2), extensive gingival bleeding (n: 2), gross gastrointestinal system bleeding (n: 2), and menorrhagia causing anemia (n: 2). PC was $<3,000 / \mu 1$ during ICH in both cases. PC during major bleeding episode was under $5.000 / \mu 1$ in 13 patients $(71 \%), 8000$ in 2 , 15000 in 1 and 24000 in 1 patient(s). There was history of a viral infection in 81 (51.9\%), vaccination in $14(8.9 \%)$ children.

Initial laboratory investigations for antinuclear antibodies, immune globulin levels and Coombs test were negative in all patients. Viral screen was performed in 48 patients, and serologic evidence for recent viral infection (elevated $\operatorname{IgM}$ ) was found $12(25 \%)$ (EBV in 6, CMV in 3, hepatitis A in 2 patient and rubella in 1 patient each). 


\section{Acute ITP}

A total of 112 children with newly diagnosed acute ITP were given prednisolone treatment (Table II). The proportions of complete and partial responders were $23.2 \%$ and $76.7 \%$ on day 4 and $48.2 \%$ and $87.5 \%$ on day 8 , respectively. Of the fourteen patients in whom PC did not increase from baseline within the first week, eight achieved $\mathrm{CR}$ in the third week while the other six did not respond to further treatment with IVIG and became chronic ITP.

At the end of week 4, 96\% of children still had normal PCs. None of the children experienced a major bleeding episode or fatal bleeding after the start of prednisolone treatment.
Twenty-two children were given IVIG. As seen in Table II, the rates of platelet recovery on day 4 and day 8 were not significantly different from that obtained with prednisolone.

There were 4 children who were treated with 30 $\mathrm{mg} / \mathrm{kg}$ MDMP for 3 days and 10 children who were observed without treatment. Although the number of subjects in these groups was not sufficient for a sound statistical comparison, the rate of platelet recovery was close to that observed in IVIG MDMP groups.

\begin{tabular}{|c|c|c|c|c|c|}
\hline & $\begin{array}{l}\text { Prednisolone } \\
\mathrm{n}(\%)\end{array}$ & $\begin{array}{l}\text { IVIG } \\
\mathrm{n}(\%)\end{array}$ & $\begin{array}{l}\text { MDMP } \\
\mathrm{n}(\%)\end{array}$ & $\begin{array}{l}\text { No therapy } \\
\mathrm{n}(\%)\end{array}$ & $\begin{array}{l}\text { P-value } \\
\mathrm{n}(\%)\end{array}$ \\
\hline Number of patients & 112 & 30 & 4 & 10 & \\
\hline $\begin{array}{l}\text { Platelet }>20,000 / \mu l \\
\text { 4th day } \\
\text { 8th day } \\
1 \text { st month }\end{array}$ & $\begin{array}{l}86(76.7) \\
98(87.5) \\
112(100)^{*}\end{array}$ & $\begin{array}{l}22(73.3) \\
26(86.6) \\
29(96.6)^{*}\end{array}$ & $\begin{array}{l}3(75) \\
3(75) \\
4(100) \\
\end{array}$ & $\begin{array}{l}4(40) \\
8(80) \\
10(100)\end{array}$ & $\begin{array}{c}>0.05 \\
>0.05 \\
0.05^{*}\end{array}$ \\
\hline $\begin{array}{l}\text { Platelet }>150,000 / \mu 1 \\
\text { 4th day } \\
\text { 8th day } \\
1 \text { st month }\end{array}$ & $\begin{array}{l}26(23.2) \\
54(48.2) \\
96(85.7)\end{array}$ & $\begin{array}{l}3(10) \\
16(53.3) \\
24(80)\end{array}$ & $\begin{array}{l}2(50) \\
3(75) \\
4(100)\end{array}$ & $\begin{array}{l}2(20) \\
4(40) \\
6(60)\end{array}$ & $\begin{array}{l}>0.05 \\
>0.05 \\
>0.05\end{array}$ \\
\hline $\begin{array}{l}\text { Recurrence } \\
(\mathrm{PC}<150,000 / \mu \mathrm{l})\end{array}$ & $14(12.5)$ & $3(10)$ & $1(25)$ & $2(20)$ & $>0.05$ \\
\hline Retreatment during follow-up & $9(8)$ & $2(6.6)$ & $1(25)$ & $1(10)$ & $>0.05$ \\
\hline Chronicity (16\%) (n: 23) & $8(7.1)$ & $2(6.6)$ & 0 & 0 & $>0.05$ \\
\hline
\end{tabular}

\section{Relapses}

Twenty children who had achieved CR relapsed. Relapse rate was $12.5 \%$ in prednisolone group, $10 \%$ in IVIG group, $25 \%$ in MDMP group and $20 \%$ in NT group (Table II).

\section{Chronic ITP}

Of the 156 children with acute ITP, twelve months after diagnosis and defined as chronic ITP. These patients were analyzed with children who were admitted with previously diagnosed chronic ITP (n: 36), making a total of 46 patients with chronic ITP. As seen in Table I, mean age and female/male ratio were higher in patients with chronic ITP as compared to children with acute ITP. Therapy in chronic ITP group consisted of MDMP in 12, IVIG in 5, prednisolone in 9, rituksimab in 2, and IVIG plus prednisolone in 12 patients. Responses to treatment and recurrence rate are shown in Table III. There were no patients who underwent splenectomy. 


\begin{tabular}{|c|c|c|c|}
\hline & $\begin{array}{l}\text { Acute ITP } \\
(\mathrm{N}: 156)\end{array}$ & $\begin{array}{l}\text { Chronic ITP } \\
(\mathrm{N}: 36)\end{array}$ & P-value \\
\hline Age (years) & $\begin{array}{l}5.39 \pm 1.91 \\
(4 \text { months- } 16 \text { years })\end{array}$ & $\begin{array}{l}7.11 \pm 2.78 \\
(2-17 \text { years })\end{array}$ & 0.001 \\
\hline Sex & $0.90(74 / 82)$ & $1.11(19 / 17)$ & $>0.05$ \\
\hline $\begin{array}{c}\text { Initial platelet counts }\left(\mu 1^{-1}\right) \\
\text { Mean } \\
\text { Range }\end{array}$ & $\begin{array}{l}8800 \pm 3130 \\
1000-21000\end{array}$ & $\begin{array}{l}20800 \pm 5420 \\
2000-51000\end{array}$ & $<0.001$ \\
\hline History of viral infection & $81(51.9 \%)$ & $4(11.1 \%)$ & $<0.001$ \\
\hline History of vaccination & $14(8.9 \%)$ & $2(5.5 \%)$ & $>0.05$ \\
\hline Hemorrhage & $\begin{array}{l}46(29.4 \%) \\
8200 \pm 3410\end{array}$ & $\begin{array}{l}17(47.2 \%) \\
13200 \pm 4720\end{array}$ & $>0.05$ \\
\hline Major Bleeding & $16(10.2 \%)$ & $4(11.1 \%)$ & $>0.05$ \\
\hline
\end{tabular}

ITP: Immune thrombocytopenic purpura. PC: Platelet count.

Table III. Platelet Response to Treatment and Recurrence in Chronic ITP

\begin{tabular}{|l|c|c|c|c|c|}
\hline & $\begin{array}{c}\text { Prednisolone } \\
\mathrm{n}\end{array}$ & $\begin{array}{c}\text { IVIG } \\
\mathrm{n}\end{array}$ & $\begin{array}{c}\text { MDMP } \\
\mathrm{n}\end{array}$ & $\begin{array}{c}\text { IVIG+prednisolone } \\
\mathrm{n}\end{array}$ & $\begin{array}{c}\text { Rtk } \\
\mathrm{n}\end{array}$ \\
\hline $\begin{array}{l}\text { Platelet count } \\
150,000\end{array}$ & 5 & 2 & 7 & 8 & 1 \\
\hline $\begin{array}{l}\text { Platelet count } \\
20,000-150,000\end{array}$ & 2 & 1 & 3 & 3 & 1 \\
\hline No response & 1 & 1 & 1 & 0 & 0 \\
\hline Recurrence & 1 & 1 & 1 & 1 & 0 \\
\hline
\end{tabular}

MDMP: Mega-dose methyl prednisolone. IVIG: Intravenous immunoglobulin. Rtk: Rituksimab. PC: Platelet count.

\section{DISCUSSION}

Idiopathic thrombocytopenic purpura (ITP) is a common pediatric hematologic disorder. The estimated incidence is $2-8$ per 100,000 population per year ${ }^{8}$. Apresumptive diagnosis of ITP is made when the history, physical examination, complete blood count, and examination of the peripheral blood smear do not suggest other etiologies for the thrombocytopenia. There is no "gold standard" test that can reliably establish the diagnosis ${ }^{9}$. Bone marrow examination is unnecessary in patients with the typical features of ITP, irrespective of the age of the patient. In one study none of 296 cases with bone marrow evaluation was the diagnosis changed by the procedure ${ }^{10}$. Bone marrow evaluation is thus not routinely needed and can be reserved for patients with atypical features or in 
cases who respond minimally or not at all to firstline therapies ${ }^{11}$. Direct Coombs test and antinuclear antibodies- considered in potentiel benefit group- (proven) were negative in all patients.

There was a history of a previous infection in approximately $50 \%$ of pediatric cases. We found serological evidence for a recent viral infection with common viruses in $51.9 \%$ of acute ITP and $11.1 \%$ in chronic ITP patients at diagnosis.

Life-threatening bleeding was defined as intracranial hemorrhage (ICH) and/or severe hemorrhage at any site requiring blood transfusion. Major hemorrhage has been reported at $17 \%$ in a retrospective review ${ }^{12}$. In our study, we found a similar incidence $(10.2 \%$ vs. $11.1 \%)$. Severe bleeding is more likely in children with platelet counts less than $10 \times 10^{9} / \mathrm{L}^{13}$. The incidence of $\mathrm{ICH}$ in children with ITP is approximately $0.1 \%$ to $0.5 \%{ }^{14}$, and predicting with confidence which children will develop an ICH is not possible. Risk factors for ICH in children with severe thrombocytopenia include head trauma and concomitant use of medications that adversely affect platelet function. The incidence of ICH among our 42 patients with ITP $(2.7 \%)$ was similar with the figure of $2.2 \% \mathrm{ICH}$ in ITP previously reported ${ }^{15}$.

The most appropriate initial therapy for children with apparent ITP remains controversial. There are 2 opinions expressed by pediatric hematologists: (1) Watch and wait with the expectation of a mild clinical course and spontaneous resolution in most patients or (2) initiate treatment to lessen the risk of significant bleeding (george).

The ASH guidelines of 1996 suggested treatment with IVIG or glucocorticoids for children with platelet counts of $<20 \times 10^{9} / \mathrm{L}$ and significant mucous membrane bleeding and for those with counts of $<10 \times 10^{9} / \mathrm{L}$ and minor purpura (george). They also recommended hospitalization and treatment intervention in a child with severe, lifethreatening bleeding regardless of the platelet counts and for a child with platelet counts of $<20 \times 10^{9} / \mathrm{L}$ and mucous membrane bleeding. Current opinion favors consideration of multiple factors when deciding to treat or not to treat children with ITP, including bleeding symptoms, the platelet count, and psychosocial and lifestyle issues such as activity profiles (provan).

In our study group, $75 \%$ of major bleedings occurred when PCs were less than $10,000 / \mu 1$ and both cases of $\mathrm{ICH}$ occurred with a PC of
$<3,000 / \mu 1$ as recommendation that patients with $\mathrm{PC}<5,000 / \mu 1$ should receive IVIG or steroid to prevent lifethreatening bleedings.

In our study, most of the patients (93\%) were treated at diagnosis either with corticosteroids or IVIG. Treatment response for drug treatment is similar to the ITP practice guidelines developed by the American Society of Hematology ${ }^{16}$. Various studies also reported that the therapy response to prednisolone and IVIG treatments were similar (watts,provan). Thus, the treating physician can prescribe any of the 3 options with confidence based on individual patient characteristics. The ASH guidelines of 1996 suggested treatment for children with platelet counts of $<20 \times 10^{9} / \mathrm{L}$ and significant mucous membrane bleeding and for those with counts of $<10 \times 10^{9} / \mathrm{L}$ and minor purpura ${ }^{16}$. They also recommended hospitalization and treatment intervention in a child with severe, lifethreatening bleeding regardless of the platelet counts and for a child with platelet counts of $<20 \times 10^{9} / \mathrm{L}$ and mucous membrane bleeding.

If the decision is made to treat patients with childhood ITP, the next question is what available therapy to recommend. Our study demonstrate 80$100 \%$ response rates with the common therapies, including prednisolone, MDMP, IVIG. Thus, the treating physician can prescribe any of the 3 options with confidence based on individual patient characteristics. Steroids are preferable due to its lower price and ease of administration as compared to IVIG. However, the use of IVIG is increasing. Whether therapy is prescribed or not, patient and parent education and ongoing follow up are crucial.

The rate of CR on day 1 st month was $100 \%$ with prednisolone and this reslut was significantly higher response rate than we observe usage of IVIG ( $p=0.052)$. The rates of CR among patient groups treated with MDMP and IVIG and the NT group were not significantly different, albeit a significantly higher response rate was obtained on day 4 with conventional dose OP. Limitations of present study included information bias as well as selection bias, and restricted number of patients. There would be less conflict about the treatment of ITP with the commonly used drugs if they were entirely safe and inexpensive.

\section{CONCLUSION}

In conclusion, severe bleedings are rare in childhood ITP despite the fact that the majority of patients present with severe thrombocytopenia. Most of cases of ITP needed treatment with one or 
more of the available options. Whether to provide pharmacologic therapy to increase the platelet count is an individual decision between the pediatrician and the patient/patient's family. So each patient requires an individual decision on the best therapy. Watchful waiting, corticosteroids or intravenous immunoglobulin are equally effective treatments and overall prognosis was found to be good. Prednisolone appears to be a less expensive first-line therapy option for treatment of patients with ITP.

\section{REFERENCES}

1. Rodeghiero F, Stasi R, Gernsheimer T, et al. Standardization of terminology, definitions and outcome criteria in immune thrombocytopenic purpura of adults and children: Report from an international working group. Blood. 2009; 113: 23-86.

2. Cines DB, Blanchette VS. Immune thrombocytopenic purpura. N Engl J Med. 2002; 346: 995-1008.

3. Rehman A. Acute immune thrombocytopenic purpura in children. Turk J Hematol. 2007; 24: 41-51.

4. Kühne $\mathrm{T}$, Imbach $\mathrm{P}$, Bolton-Maggs $\mathrm{PH}$, Berchtold W, Blanchette V, Buchanan GR, Intercontinental Childhood ITP Study Group. Newly diagnosed idiopathic thrombocytopenic purpura in childhood: an observational study. Lancet 2001; 358: 2122-25.

5. Kumar M, Vik TA, Johnson CS, Southwood ME, Croop JM. Treatment, outcome, and cost of care in children with idiopathic thrombocytopenic purpura. Am. J. Hematol 2005; 78: 181-7.

6. British Committee for Standards in Haematology General Haematology Task Force. Guidelines for the investigation and management of idiopathic thrombocytopenic purpura in adults, children and in pregnancy. Br J Haematol 2003; 120: 574-96.

7. Ancona KG, Parker RI, Atlas MP, Prakash D. Randomized trial of high-dose methylprednisolone versus intravenous immunoglobulin for the treatment of acute idiopathic thrombocytopenic purpura in children. J Pediatr Hematol Oncol 2002; 24: 540-544.

8. Benesch M, Kerbl R, Lackner H, et al. Low dose versus high-dose immunoglobulin for primary treatment of acute immune thrombocytopenic purpura in children: results of a prospective, randomized single-center trial. J Pediatr Hematol Oncol. 2003; 25: 797-800.
9. Provan D, Stasi R, Newland AC, et al. International consensus report on the investigation and management of primary immune thrombocytopenia. Blood 2010; 115: 168-86.

10. Watts RG. Idiopathic thrombocytopenic purpura: a 10-year natural history study at the Children's Hospital of Alabama. Clin Pediatr 2004; 43: 691-702.

11. Klaassen RJ, Doyle JJ, Krahn MD, Blanchette VS, Naglie G. Initial bone marrow aspiration in childhood idiopathic thrombocytopenia: decision analysis. J Pediatr Hematol Oncol. 2001; 23: 51118.

12. Medeiros D, Buchanan GR. Major hemorrhage in children with idiopathic thrombocytopenic purpura: immediate response to therapy and long-term outcome. J Pediatr 1998; 133: 334-9.

13. Butros LJ, Bussel JB. Intracranial hemorrhage in immune thrombocytopenic purpura: a retrospective analysis. J Pediatr Hematol Oncol. 2003; 25: 660-4.

14. Imbach $\mathrm{P}$, Kuhne $\mathrm{T}$, Muller $\mathrm{D}$, et al. Childhood ITP: 12 months follow-up data from the prospective registry I of the Intercontinental Childhood ITP Study Group (ICIS). Pediatr Blood Cancer. 2006; 46: 351-6.

15. Choudhary DR, Naithani R, Mahapatra M, Kumar R, Mishra P, Saxena R. Intracranial hemorrhage in childhood immune thrombocytopenic purpura. Pediatr. Blood Cancer.2009; 52: 529-31.

16. George JN, Woolf SH, Raskob GE, et al. Idiopathic thrombocytopenic purpura: a practice guideline developed by explicit methods for the American Society of Hematology. Blood 1996; 88: 3-40. 